\title{
Investigating the Effect of Amanah Ikhtiar Malaysia's Microcredit Program on Their Clients Quality of Life in Rural Malaysia
}

\author{
Abdullah- Al- Mamun \\ Centre for Social Entrepreneurship, Binary University College, 47100 Puchong, Malaysia \\ Tel: 60-16-215-7752 E-mail: mamun.freethinker@gmail.com \\ Joseph Adaikalam \\ Centre for Social Entrepreneurship, Binary University College, 47100 Puchong, Malaysia \\ Tel: 60-3-8070-6590 E-mail: joseph@binary.edu.my
}

Sazali Abdul Wahab

National Defense University of Malaysia, Kuala Lumpur, 57000, Malaysia

Tel: 60-3-9051-3060Ｅ-mail: saw@upnm.edu.my

\author{
Received: July 8, 2011 \\ Accepted: August 1, 2011 \\ Published: January 1, 2012 \\ doi:10.5539/ijef.v4n1p192 \\ URL: http://dx.doi.org/10.5539/ijef.v4n1p192
}

This study was conducted under the project titled "Fighting Against Poverty" funded by The Centre for Social Entrepreneurship, Binary University College

\begin{abstract}
The objective of this study is to examine the impact of Amanah Ikhtiar Malaysia's (AIM) microcredit program on their poor client's quality of life in rural Malaysia. AIM provides small scale financial services and training to poor and hardcore poor households in order to improve their socio-economic condition. This study employed a cross-sectional design with stratified random sampling method to examine whether participation in AIM's microfinance programs improves poor rural households quality of life. A quality of life index using eleven selected indicators was developed. Findings of this study extend the literature by providing empirical evidence that access to microfinance improved quality of life of the poor rural households in Malaysia. The findings show that respondent's participation status is associated with the size and quality of their houses. AIM should therefore focus on increasing the outreach as well as review and re-organize their programs in order to offer a dynamic and well-diversified microfinance program to fulfill all financial needs of their poor clients in rural areas.
\end{abstract}

Keywords: Microfinance, Poverty, Quality of life, Welfare, Malaysia

\section{Introduction}

The poverty rate in Malaysia has declined dramatically after its independence. While $49.3 \%$ of Malaysian households lived below the poverty line in 1970, the poverty rate has reduced significantly to $16.5 \%$ in 1990 , and further declined to $3.6 \%$ in 2007 (Midterm Review of $9^{\text {th }}$ Malaysia Plan). The reduction in poverty rate can be attributed to the rapid economic growth in Malaysia which generated higher-paid employment opportunities and profitable micro and small-scale businesses opportunities in Malaysia (Economic Report, 2008/09). Moreover, the government of Malaysia implemented several strategies to increase productivity, diversify sources of income and improve the quality of life of the poor. These poverty reduction strategies were the integrated and integral part of Malaysia's core development plans. The government encourages and works together with private sectors and state based poverty eradication foundations. The leading organizations working toward socio-economic development of the poor and hardcore poor households in Malaysia includes (1) Tabung Ekonomi Kumpulan Usahawan National (National Entrepreneurs Economic Group Fund - TEKUN), (2) Agrobank, (3) Lembaga Kemajuan Ikan Malaysia (Malaysia Fisheries Development Board - LKIM), (4) Yayasan Basmi Kemiskinan (Poverty Eradication Foundation -YBK) and (5) Amanah Ikhtiar Malaysia. 
However, the client selection process as well as product and services offered by each program are not same. TEKUN was established in 1998 as a foundation under Ministry of Entrepreneur Development and Cooperatives, Malaysia, to provide loans only to Bumiputra's who own and are directly involved in any business not necessarily from the poor or hardcore poor group. Agrobank provides microcredit to all Malaysian micro-entrepreneurs, which they labeled as 'Entrepreneur Capital 1 Malaysia', and this scheme is not primarily focusing on poor and hardcore poor households in Malaysia. LKIM was established to offer several small scale credit services to improve the socio-economic status of the fishing community only and the fishermen does not necessarily have to be poor or hardcore poor. YBK was launched by the State Government of Selangor and it provides financial services only to selected participants from the State. The objectives of YBK are to produce entrepreneur and small scale businessman and to improve the quality of life of hardcore poor households in Selangor, Malaysia.

AIM on the other hand was established in 1987, to provide small scale financial services and training to poor and hardcore poor only, in order to improve their socio-economic condition. AIM uses a group based Grameen Bank (a Bangladeshi microfinance organization) model, which has been replicated by many MFO's all over the world. AIM selects their clients based on clients' average monthly household income. Households with average monthly household income below the poverty line income (PLI has been calculated by the Malaysian government since 1976. It was estimated based on the necessity of food and other basic needs) would be considered as absolute poor, while households with average monthly household income below half of the PLI would be categorized as hardcore poor. AIM only selects those households, whose average monthly household income falls below the PLI, which includes both poor and hardcore poor households.

AIM provides three economic loans namely I-Mesra loan, I-Srikandi loan and I-Wibawa loan. AIM also provides I-Penyayang loan or recovery loan. In addition, AIM provides education loan (I-Bistari) and housing/multipurpose loan known as I-Sejahtera. No legal action would be taken if the borrowers fail to settle their payments. As at August 2010, AIM has extended their outreach to 87 branches in Malaysia. There are 60497 groups in 6646 centers, currently serving a total of 254,116 clients achieving a 99.42\% repayment rate (AIM, 2010) from all the loans disbursed. AIM is the only microfinance organization operating at national level and reaching to more than $82 \%$ of the poor and hardcore poor households in Malaysia. In view of its wide coverage, this study therefore selected AIM in order to measure the impact of microcredit program on the quality of life of poor rural households in Malaysia.

\section{Literature Review}

Microcredit came into existence nearly two decades ago to fulfill the need for basic financial services of nearly half of the world's population (Abed, 2000). Microcredit is established to uplift poor people and bring them out of poverty by lending small amount of collateral free credit for small scale income generating activities (Rosenberg, 2010). The Asian Development Bank (2009) defines microcredit as the provision of a broad range of financial services such as loans, deposits, payment services, money transfer, and insurance to poor and hardcore poor households and their micro-enterprises. Consultative Group to Assist the Poor (CGAP, 2010) defined microcredit as "a credit methodology that employs effective collateral substitutes to deliver and recover short-term, working capital loans to micro entrepreneurs." The Microcredit Summit (2006) adopted the definition of microcredit as "programs to extend small loans to very poor people for self-employment projects that generate income, allowing them to care for themselves and their families." The objective of Microcredit Summit is to ensure that 175 million of the world's poorest families, especially the women in those families, receive credit for self-employment and other financial and business services before the end of 2015 (Microcredit Summit Campaign Report, 2009). As mentioned in Microcredit Summit Campaign Report (2009), "assuming five persons per family, reaching 175 million of the world's poorest families would affect 875 million family members. When 100 million families rise above the US\$1 a day threshold, half a billion people will have left extreme poverty".

Microcredit provides productive capital, which together with social capital and human capital enables the poor and hardcore poor households to move out of poverty (Otero, 1999; Abed, 2000). There is extensive literature on microcredit showing that it has a significant impact on poverty reduction around the world. Studies conducted by Hossain (1988), Mustafa et al. (1996), Khandker and Pitt (1998), Kamal (1999), Latifee (2003), Khandker (2003), Hussain and Nargis (2008), Hoque (2008), and Rahman, Rafiq and Momen (2009) on several microfinance organization's clients in Bangladesh noted that participation in microfinance programs improved poor households ability to generate income which leads to an improvement in household's income, net working capital, fixed assets, increase spending on food, medical facilities and children's schooling. A study conducted by Khandker and Pitt (1998) showed indirect improvement of household welfare by increasing market labor supply and children's schooling. Findings of Malhota, Schuler and Boender (2002) have shown that after participating in a group based microcredit program, women become more conscious about their family welfare, which ultimately leads to positive outcomes in child health and education as well as household wellbeing. Latifee (2003) in his study on Grameen 
Bank's microcredit clients in Bangladesh mentioned that about $90 \%$ of the borrowers reported an improvement in standard of living. Studies conducted by Sutoro (1990) in Indonesia, Sebstad and Walsh (1991) in Nairobi, Mosley (1996) in Bolivia, Dunn (2005) in Bosnia and Herzegovina, Panda (2009) in India also noted similar positive impacts of microcredit.

The impact of AIM's microfinance schemes followed a similar pattern, as it does for others. Study conducted by Sukor and Gibbons (1990) discovered a significant 55\% increase in client's monthly household income. The Second Internal Impact Study, (1990) conducted by Research and Development Unit, AIM, showed further overall improvement among participating households. Around $98 \%$ of them experienced an increase in household income compared to $70 \%$ from the first study. The per capita monthly income also increased from RM40 to RM73. The Third Internal Impact Study (1994) measured the impact on quality of life, by analyzing the ownership and quality of housing, type and quality of household assets, agricultural land and savings. Findings of this study also noted that increase in household income enables the participants to improve their housing conditions. Household savings increased from an average RM33.11 to RM211.25. The increase in household income also facilitated an increase in expenditure on food, nutrition, education and reinvestment.

Earlier researches used a wide range of indicators to measure the quality of life of the households' of microfinance organizations clients. Snodgrass and Sebstad (2002) conducted an impact study in three MFO's; SEWA Bank in India; Mibanco in Peru and Zambuko Trust in Zimbabwe. The indicators they used to measure households quality of life in India include materials used in the Walls, Floor and Roof, number of rooms, number of floors, separate room for a kitchen, separate household plot, separate house/ room/ building, have electricity, sources of water, light and cooking fuel. Uotila (2005), in his impact assessment in Rwanda, measured the quality of life of microfinance clients households based on their sources of drinking water, cooking fuel, toilet facilities and children in school. The Third Internal Impact Study (1994) measured their client's household's quality of life by using the following indicators, owner occupied house, use of electric household products, ownership of agricultural land, perception of nutritional quality and voluntary savings. After reviewing the earlier studies, this study selected the following variables to measure the impact of AIM's microfinance schemes on poor rural household's quality of life - size of the house, number of storey, number of rooms, structural condition, materials used in walls, roof and floor; sources of drinking water, cooking fuel, toilet facilities and sources of light

\section{Research Methodology}

\subsection{Conceptual Model and Hypothesis}

As mentioned by Hulme (1997), "behind all microfinance programs is the assumption that intervention will change human behaviors and practices in ways that lead to the achievement (or raise the probability of achievement) of desired outcomes." The conceptual model of impact chain presents a complex set of links as each 'effect' becomes a 'cause' in its own right generating further effects. One of the most complex conceptual models for impact assessment was presented by Chen and Dunn (1996), called the household economic portfolio model (HHEP), where researchers explained the effect of credit on household resources and household activities only. This study however only measures one of the implications of Household Economic Portfolio Model; which is hypothesized as $\left(H_{l}\right)$ 'participation in microcredit program lead to an improvement in households' quality of life in Rural Malaysia'.

\subsection{Research Design}

As mentioned by Montgomery and Weiss (2011), impact assessment methodology addressed how participation in microcredit program affects selected variables with how those same selected variables would have performed in the absence of microcredit program. The most appropriate method to address the question should be by employing an experimental design. Since it is just not possible to control all the factors while measuring the impact of microcredit (Hulme, 2000), therefore, full experimental approach is not feasible to assess the impact of microcredit programs (see also Khandker and Pitt, 1998; Swain and Varghese, 2009; Montgomery and Weiss, 2011), this study therefore used a quasi-experimental approach to measure the impact of microcredit. In quasi-experimental approach control and treatment groups are used to measure the impact of AIM's microcredit programs. Moreover, in Malaysia, AIM provides financial services to more than 82 percent of the poor households. The rest of the poor and hardcore poor households are more likely to receive financial aid from other government and non-government development agencies or projects. It is also highly likely that these poor households live in remote locations therefore are unable to form a five member group and participate in weekly center meetings and/or they just do not want to participate in AIM's microcredit program. To minimize the difference between the control and the treatment group (participating more than 12 months), this study therefore selects the control group (participating less than or equal to 12 months) from AIM's client base. This study also used before and after method to measure the impact of microcredit on poor rural household's quality of life. 
This research employed a cross-sectional design to measure the impact of AIM's microcredit schemes in Peninsular Malaysia. This study adopted the group statistics that has been most often used known as 'average effect of treatment of treated', which measures the impact on the outcome of one group compared to others. The average program impact is estimated by comparing the average outcome of the members of treatment group (old respondents) with the same average outcome of the members of the control group (new respondents).

\subsection{Sample Selection and Data Collection}

This research employed a stratified random sampling method and collected data through face-to-face structured interviews. AIM's microcredit program currently offers financial services through 87 branches in Malaysia. Among the 87 branches, 7 branches were randomly selected from five states, where poverty rate is relatively higher compared to other states. Out of seven branches, two were from Kedah (Cawangan Baling and Cawangan Pendang), two were from Kelantan (Cawangan Machang and Cawangan Tumpat) and one branch each from Perlis (Cawangan Perlis), Perak (Cawangan Batang Padang) and Terengganu (Cawangan Besut). A team of nine Research Assistants together with the Project Manager then visited each of the branches from $18^{\text {th }}$ April, 2011 to $9^{\text {th }}$ May, 2011. Respondents were randomly selected during the centre meetings. After the data collection team had explained the purpose of the study a total of 286 respondents agreed to be interviewed and complete data were collected from a total of 281 poor rural clients, of whom 34 were new clients and 247 were old clients

\section{Summary of Findings}

\subsection{Housing Conditions}

Respondents housing conditions were assessed based on the size of the house, number of storey of the house, number of rooms in the house and structural conditions of the house. The percentage distribution of size of home for new and old respondents is presented in Table 1. The $p$-value for Pearson's Chi-Square tests indicates an association between respondents participation status with the size of the house they living in $(p$-value $=0.000<0.05)$. Moreover, a relatively higher percentage of new respondents reported that they are living in smaller houses compared to the old respondents. The $p$-value for Pearson's Chi-Square tests indicates an association between respondents membership status (new and old) with the size of the house they live in ( $p$-value $=0.000<0.05$ ).

The $p$-value for the Wilcoxon Signed Ranks test is 0.034 , which is less than the preferred $5 \%$ level of significance, indicating a significant difference in the mean size of the house; the mean size of the houses of respondents after participation is significantly bigger than the size of the house before the participation. Moreover, the $p$-value for the Mann-Whitney test is 0.010 , which is less than the chosen $5 \%$ level of significance, indicating a significant difference in the mean size of the house; the mean size of the houses of old respondents is significantly bigger than the mean size of houses of new respondents.

On the number of storeys of the houses, only 11 out of 281 respondent, reported that they are currently living in houses with more than two storeys, which is higher than that recorded before participation. The $p$-value for Pearson's Chi-Square tests indicates an association between respondents participation status - before and after, with the number of storeys of the house they live in $(p$-value $=0.000<0.05)$. The $p$-value for the Wilcoxon Signed Ranks is 0.020 , which is less than the chosen $5 \%$ level of significance and this indicates that more respondents are staying generally in multi-storey houses after participating AIM's microcredit program.

Table 2 presents the details about the number of rooms and structural condition of the houses of new and old respondent's as well as the changes after participation. The $p$-value for Pearson's Chi-Square tests indicates that respondent's participation status (before and after) is associated with the number of rooms in the house they are living in. Only 7 out of 281 respondents reported that the number of rooms in their houses increased after participation. The $p$-value for the Wilcoxon Signed Ranks is 0.000 , which is less than the chosen $5 \%$ level of significance, indicating a significant difference in the mean number of rooms per house respondents are living in before and after participation.

With regard to the structural condition of the house respondents are living in, only 11 out of 281 respondents reported that the structural condition of their house is better than before participation. The $p$-value for Pearson's Chi-Square tests indicates that respondent's participation status (before and after) is associated with the structural condition of the house they are living in. The $p$-value for the Wilcoxon Signed Ranks is 0.000 , which is less than the chosen $5 \%$ level of significance. On the whole the structural conditions of the house after participation is significantly better than before participation.

\subsection{Housing Materials}

To grade the materials used for the walls, floor and roofs of the houses, respondents were asked to answer from eight options which include the most common housing materials, such as cement/stone, wooden boards, plastics or 
cardboard, zinc/tin, bamboo and others. Materials used were then divided into two groups, namely permanent materials and temporary materials. The types of housing materials used to construct walls, floor and roofs of the houses, new and old respondents are currently living in as well as before and after participating in AIM's microcredit program are presented in Table 3.

More than $80 \%$ of the total rural respondents reported that they used temporary material for the walls of their house. $84.3 \%$ respondents reported that they used temporary housing materials for the floor of the house and $98.9 \%$ respondents reported that they used temporary housing materials in the roofs of their houses. Out of 281 respondents, 14 households changed housing materials from temporary to permanent for walls of their houses. The $p$-value for Pearson's Chi-Square tests indicates that respondent's participation status (before and after) is associated with the materials used to construct walls of their houses. It is noted that the $p$-value for the Wilcoxon Signed Ranks is less than the chosen $5 \%$ level of significance indicating that the mean value for materials used for walls before and after participation in AIM's microcredit program is significantly different

\subsection{Other Welfare Indicators}

Other household welfare variables include household's toilet facilities, cooking fuel, sources of light and sources of drinking water. Findings from this study indicate that in rural Peninsular Malaysia, only 8 out of 281 respondents are reported to have no access to environmentally safe toilet facilities (Flash / Cement Toilet) and 8 out of 281 respondents reported that they use environmentally more destructive cooking fuel. On sources of drinking water, total 19 out of 281 rural respondents reported not having access to tap water. The number and percentage of new and old respondents having access to safe sources of drinking water, cooking fuel and toilet facilities are presented in Table 4.

Findings of this study indicate that $93.2 \%$ households currently have access to safe drinking water, $97.2 \%$ households use environmentally less distractive cooking fuel and $97.2 \%$ of respondents used environmentally safe toilet facilities in rural Peninsular Malaysia. The $p$-value for Pearson's Chi-Square tests indicates that respondent's participation status (before and after) is associated with the sources of drinking water and sources of cooking fuel. The $p$-value for the Wilcoxon Signed Ranks is less than the chosen 5\% level of significance indicating that the sources of drinking water and sources of cooking fuel used by the respondent's households are significantly better than before participation

\subsection{Testing Research Hypothesis 1}

The mean quality of life index score for 281 rural clients before and after participation in AIM's microcredit program are presented in Table 5 . The mean quality of life score after participation is relatively higher than that before participation. The standard deviation of quality of life score also decreased after participation. The $p$-value for Wilcoxon Signed Ranks test is 0.000 , which is less than chosen 5\% level of significance, which indicates that the mean difference in quality of life index score is statistically significant. It is therefore concluded that participation in AIM's microcredit program does lead to an improvement in client's quality of life in rural Peninsular Malaysia.

\section{Conclusion and Recommendation}

This study assessed the impact of AIM's microcredit program on the quality of life of poor clients households in rural Peninsular Malaysia. Since the objective of AIM's microcredit program is to improve socio-economic condition of poor households in Malaysia, findings of this study therefore improve AIM's knowledge and understanding about the effectiveness of current microcredit program on household's quality of life.

As per the findings presented above, this study concludes that participation in AIM's microcredit program leads to an improvement in poor rural household's quality of life in Peninsular Malaysia. These findings are consistent with earlier research findings conducted to measure the impact of AIMs microfinance schemes on their client's quality of life as well as studies conducted around the world. These studies include SERU (1990) impact study; the Third Internal Impact Study (1994); Snodgrass and Sebstad (2002) in India, Peru and Zimbabwe; Uotila (2005) in Rwanda; and Latifee (2003) in Bangladesh.

The findings of this study have vital implications for academics, AIM, poor rural households, as well as the development economists and policy makers. For academicians, findings of this study indicate the importance of measuring impact of microcredit program on quality of life too instead of focusing only on income and asset. For AIM policy makers, these findings indicate the effectiveness of the program they practised since 1987. For rural poor households and for the economists and development policy makers, these findings indicate that participation in AIM's microcredit program can be a useful mechanism to improve the quality of life of rural poor households in Peninsular Malaysia. 
AIM therefore has to intensify its efforts in order to increase the number of poor as well as less poor or low income group by offering them with a well-diversified products and services. It is therefore proposed that AIM should review current microfinance products and methodology and organize them in a way which can benefit their clients most.

\section{References}

Abed, H. F. (2000). Microfinance NGOs in Bangladesh Growth, Impact and Challenges, Paper presented at the Asian Regional Conference on The Potential and Limitations of Economic Initiatives in Grassroots Development Current Issues and Asian Experiences, 27th - 30th November 2000.

Amanah Ikhtiar Malaysia. (2010). Achievement as of 31 August 2010. [online] Available: http://www.aim.gov.my (09.12.2010)

Asian Development Bank. (2009). Microfinance Development Strategy, [Online] Available: http://www.adb.org/Documents/Policies/Microfinance/microfinance0100.asp?p=policies (12.01.2009)

Baker, J. and Schuler, N. (2004). Analyzing Urban Poverty: A summery of Methods and Approaches, World Bank Policy Research Working Paper - 3399. the World Bank.

CGAP. (2006). Good Practice Guidelines for Funders of Microfinance, Available at http://www.cgap.org/p/site/c/template.rc/1.9.2746/ (11.12. 2007).

CGAP. (2010). what is Microfinance? [Online] Available: http://www.microfinancegateway. org $/ \mathrm{p} / \mathrm{site} / \mathrm{m} /$ template.rc/1.26.9183/\#1 [2010, January 16]

Chen, M A., \& Dunn, E. (1996). Household Economic Portfolios, Washington DC: Management Systems International

Datta. (2004). Microfinance in rural Bangladesh: Is it reaching the poorest? Journal of Microfinance, Vol. 6, no-1, pp 59.

Dunn, E. (2005). Impact of Microfinance on Clients in Bosnia and Herzegovina, Foundation for Sustainable Development of the Federation of Bosnia and Herzegovina and Republika Srpska Development and Employment Foundation.

Gibbons, D. S., \& Kasim, S. (1990). Banking on the Rural Poor, Center for Policy Research, University Science Malaysia, Malaysia

Harris, S. D. (2006). Microcredit Summit Campaign Report -2006, [Online] Available: www.microcreditsummit.org/pubs/reports/socr/2006/SOCR06.pdf [2008, December 21]

Harris, S. D. (2009). Microcredit Summit Campaign Report -2009, [Online] Available: http://www.microcreditsummit.org/uploads/socrs/SOCR2009_English.pdf [2010, October 11]

Hashemi, S.M. (1997). Dropouts and Leftouts: The Grameen Targeting of the Extreme Poor, Dhaka: Credit Development Forum.

Hoque, S. (2008). Does Micro-credit Program in Bangladesh Increase Household's Ability to Deal with Economic Hardships? [Online] Munich Repack Personal Archive, Paper No. 6678, Available: http://mpra.ub.uni-muenchen.de/6678/ [2008, November, 11]

Hossain, M. (1988). Credit for the Alleviation of Rural Poverty: The Grameen Bank in Bangladesh, Research Report No. 55, IFPRI, Washington DC.

Hulme, D. (1997). Impact Assessment Methodologies for Microfinance: A Review, Washington DC, CGAP.

Hussain AKM, G., \& Nargis N. (2008). A Welfare Economic Analysis of the Impact of Microfinance in Bangladesh, Department of Economics, University of Dhaka, Nilkhet, Dhaka-1000, Bangladesh.

Islam, T. (2007). Microfinance and poverty alleviation. Aldershot, England; Burlington, U.S.A.: Ashgate Publishing.

Kamal, M.M. (1999). Measuring Transformation: Assessing and Improving the Impact of Microfinance. Impact Evaluation Mechanism of the Association for Social Advancement (ASA) in Bangladesh

Khandker, S. R. (2003). Microfinance and Poverty: Evidence Using Panel Data from Bangladesh, World Bank Policy Research Working Paper 2945, Washington D.C. 
Khandker, S. R., \& Pitt, M. (1998). The Impact of Group-Based Credit Programs on Poor Households in Bangladesh: Does the Gender of Participants Matter? Journal of Political Economy, Vol. 106, pp: 958-96. http://dx.doi.org/10.1086/250037

Latifee, H. I. (2003). Microfinance and Poverty Reduction, International Conference on Poverty Reduction through Microfinance. Taksim-Istambul, June 09-10, 2003.

Mid Term Review of the $9^{\text {th }}$ Malaysia Plan (2008) Economic Planning Unit, The Government of Malaysia, [Online] Available: http://www.epu.gov.my (12.10.2008)

Mosley, P. (1996). Metamorphosis from NGO to Commercial Bank: The Case of Bancosol in Bolivia. In Finance Against Poverty, Volume II: Country Case Studies, pp 1-45

Mustafa, S., Ara, I., Banu, D., Hossain, A., Kabir, A., Mohsin, M., Yusuf, A., \& Jahan, S. (1996). Beacon of Hope: An Impact Assessment of BRAC's Rural Development Programme. Research and Evaluation Department, Bangladesh Rural Development Committee, Dhaka, Bangladesh.

Otero, M. (1999). Bringing Development back into Microfinance. Journal of Microfinance, Vol-1, Issue-1 pp- 8

Panda K. D. (2009). Participation in the Group Based Microfinance and its Impact on Rural Households: A Quasiexperimental Evidence from an Indian State. Global Journal of Finance and Management, Vol: 1, No: 2, Pp: 171-183

Rahman, H. Z. (1998). Bangladesh: Dynamics of Rural Poverty, Paper presented at International Conference on Poverty, 9/11 February 1998, Dhaka, Bangladesh.

Rahman, S., Rafiq, R. B., \& Momen, M. A. (2009). Impact of Microfinance Programs on Higher Income Borrowers: Evidence from Bangladesh. International Business \& Economics Research Journal, Vol-:8, Issue: 2

Research and Development Unit. (1990). Second Impact Study, Amanah Ikhtiar Malaysia, Selangor, Malaysia Research and Development Unit. (1991-1993). Third Impact Study, Amanah Ikhtiar Malaysia, Selangor, Malaysia

Rosenberg, R. (2010). Does Microfinance Really Help the Poor People, CGAP Focus Note [Online] Available: http://www.cgap.org/gm/document-1.9.41443/FN59.pdf [2010, November 10]

Salma M. (2004). A Comparative Case Study on Outreach and Impact of Ikhtiar Loan Scheme and Special Program for Hardcore Poor in Seberang Perai Pulau Pinang. Masters Thesis, University Science Malaysia.

Sebstad, J., \& Walsh, M. (1991). Microenterprise Credit and its Effects in Kenya: An Exploratory Study. Report prepared for USAID AFR/MDI and S\&T/WID. Coopers and Lybrand, Washington, D.C.

Snodgrass, D.R., \& Sebstad, J. (2002). Client in Context: The Impact of Microfinance in three countries, Consultative Group to Assist the Poor, Washington DC: Management Systems International

Social Science and Economic Research Unit. (1990). Impact Study, Prime Ministers Department, Malaysia

Sutoro, A. D. (1990). KUPEDES Development Impact Survey: Briefing Booklet, BRI, Planning, Research and Development Department. Indonesia.

Tenth Malaysia Plan. (2010). Economic Planning Unit, The Government of Malaysia, [Online] Available: http://www.epu.gov.my (11.11.2010)

Uotila, A. (2005). Livelihood Impact of Microfinance access for the Poor: The Case of Vision FINCA Rwanda. MPhil Thesis, The University of Guelph, Canada. 
Table 1. Size of the House and Number of Storey

\begin{tabular}{|c|c|c|c|c|c|}
\hline & & \multicolumn{2}{|c|}{ Membership Status } & \multicolumn{2}{|c|}{ Participation Status } \\
\hline \multicolumn{2}{|l|}{ Size of the House } & New & Old & Before & After \\
\hline \multirow[t]{2}{*}{ Small } & $\mathrm{N}$ & 11 & 19 & 33 & 30 \\
\hline & $\%$ & $32.4 \%$ & $7.7 \%$ & $11.7 \%$ & $10.7 \%$ \\
\hline \multirow[t]{2}{*}{ Medium } & $\mathrm{N}$ & 18 & 193 & 211 & 211 \\
\hline & $\%$ & $52.9 \%$ & $78.1 \%$ & $75.1 \%$ & $75.1 \%$ \\
\hline \multirow[t]{2}{*}{ Big } & $\mathrm{N}$ & 5 & 35 & 37 & 40 \\
\hline & $\%$ & $14.7 \%$ & $14.2 \%$ & $13.2 \%$ & $14.2 \%$ \\
\hline \multirow[b]{2}{*}{ Total } & $\mathrm{N}$ & 34 & 247 & 281 & 281 \\
\hline & $\%$ & $100 \%$ & $100 \%$ & $100 \%$ & $100 \%$ \\
\hline \multirow[b]{2}{*}{ Pearson Chi-Square Test } & Value & \multicolumn{2}{|c|}{19.5568} & \multicolumn{2}{|c|}{510.5852} \\
\hline & $p$-value & \multicolumn{2}{|c|}{$0.000<0.05$} & \multicolumn{2}{|c|}{$0.000<0.05$} \\
\hline \multirow[b]{2}{*}{ Descriptive Analysis } & Mean & 0.7059 & 0.7662 & 0.7536 & 0.7589 \\
\hline & SD & 0.1682 & 0.1160 & 0.1249 & 0.1246 \\
\hline Shapiro-Wilk test of Normality & $p$-value & 0.000 & 0.000 & 0.000 & 0.000 \\
\hline \multirow[b]{4}{*}{ Testing Mean Difference } & & \multicolumn{2}{|c|}{ Mann-Whitney Test } & \multicolumn{2}{|c|}{ Wilcoxon Signed Ranks } \\
\hline & M.Rank & 115.47 & 144.51 & \multicolumn{2}{|c|}{ Positive Rank: 3} \\
\hline & Z & \multicolumn{2}{|c|}{-2.582} & \multicolumn{2}{|c|}{-2.1213} \\
\hline & $p$-value & \multicolumn{2}{|c|}{$0.010<0.05$} & \multicolumn{2}{|c|}{$0.034<0.05$} \\
\hline \multicolumn{6}{|l|}{ Number of Storey } \\
\hline \multirow[t]{2}{*}{ One } & $\mathrm{N}$ & 28 & 213 & 251 & 241 \\
\hline & $\%$ & $82.4 \%$ & $86.2 \%$ & $89.3 \%$ & $85.8 \%$ \\
\hline \multirow[t]{2}{*}{ Two } & $\mathrm{N}$ & 5 & 33 & 27 & 38 \\
\hline & $\%$ & $14.7 \%$ & $13.4 \%$ & $9.6 \%$ & $13.5 \%$ \\
\hline \multirow[t]{2}{*}{ More then Two } & $\mathrm{N}$ & 1 & 1 & 3 & 2 \\
\hline & $\%$ & $2.9 \%$ & $0.4 \%$ & $1.1 \%$ & $0.7 \%$ \\
\hline \multirow[b]{2}{*}{ Total } & $\mathrm{N}$ & 34 & 247 & 281 & 281 \\
\hline & $\%$ & $100 \%$ & $100 \%$ & $100 \%$ & $100 \%$ \\
\hline & Value & \multicolumn{2}{|c|}{2.7937} & \multicolumn{2}{|c|}{349.7331} \\
\hline Pearson Chi-Square Test & $p$-value & & & & \\
\hline & Mean & 0.7059 & 0.7662 & 0.7536 & 0.7589 \\
\hline Descriptive Analysis & SD & 0.1682 & 0.1160 & 0.1249 & 0.1246 \\
\hline Shapiro-Wilk test of Normality & $p$-value & 0.000 & 0.000 & 0.000 & 0.000 \\
\hline & & Mann & Test & Wilcox & d Ranks \\
\hline & M.Rank & 146.21 & 140.28 & Posit & $: 10$ \\
\hline & Z & & & & \\
\hline Testing Mean Difference & $p$-value & & & & \\
\hline
\end{tabular}


Table 2. Number of Rooms and Structural Condition of the House

\begin{tabular}{|c|c|c|c|c|c|}
\hline \multirow{2}{*}{\multicolumn{2}{|c|}{ Number of Rooms }} & \multicolumn{2}{|c|}{ Membership Status } & \multicolumn{2}{|c|}{ Participation Status } \\
\hline & & New & Old & Before & After \\
\hline \multirow[t]{2}{*}{ One } & $\mathrm{N}$ & 4 & 8 & 19 & 12 \\
\hline & $\%$ & $11.8 \%$ & $3.2 \%$ & $6.8 \%$ & $4.3 \%$ \\
\hline \multirow[t]{2}{*}{ Two } & $\mathrm{N}$ & 12 & 75 & 86 & 87 \\
\hline & $\%$ & $35.3 \%$ & $30.4 \%$ & $30.6 \%$ & $31.0 \%$ \\
\hline \multirow[t]{2}{*}{ Three } & $\mathrm{N}$ & 12 & 104 & 110 & 116 \\
\hline & $\%$ & $35.3 \%$ & $42.1 \%$ & $39.1 \%$ & $41.3 \%$ \\
\hline \multirow[t]{2}{*}{ More than Three } & $\mathrm{N}$ & 6 & 60 & 66 & 66 \\
\hline & $\%$ & $17.6 \%$ & $24.3 \%$ & $23.5 \%$ & $23.5 \%$ \\
\hline \multirow[b]{2}{*}{ Total } & $\mathrm{N}$ & 34 & 247 & 281 & 281 \\
\hline & $\%$ & $100 \%$ & $100 \%$ & $100 \%$ & $100 \%$ \\
\hline \multirow[b]{2}{*}{ Pearson Chi-Square Test } & Value & \multicolumn{2}{|c|}{6.2192} & \multicolumn{2}{|c|}{697.3008} \\
\hline & $p$-value & \multicolumn{2}{|c|}{$0.101>0.05$} & \multicolumn{2}{|c|}{$0.000<0.05$} \\
\hline \multirow[b]{2}{*}{ Descriptive Analysis } & Mean & 0.6471 & 0.7186 & 0.6984 & 0.7100 \\
\hline & SD & 0.2312 & 0.6931 & 002195 & 0.2079 \\
\hline Shapiro-Wilk test of Normality & $p$-value & 0.002 & 0.000 & 0.000 & 0.000 \\
\hline \multirow[b]{4}{*}{ Testing Mean Difference } & & \multicolumn{2}{|c|}{ Mann-Whitney Test } & \multicolumn{2}{|c|}{ Wilcoxon Signed Ranks } \\
\hline & M.Rank & 119.97 & 143.89 & \multicolumn{2}{|c|}{ Positive Rank: 7} \\
\hline & Z & \multicolumn{2}{|c|}{-1.709} & \multicolumn{2}{|c|}{-3.3565} \\
\hline & $p$-value & \multicolumn{2}{|c|}{$0.087>0.05$} & \multicolumn{2}{|c|}{$0.001<0.05$} \\
\hline \multicolumn{6}{|l|}{ Structural Condition of the House } \\
\hline \multirow[t]{2}{*}{ Poor } & $\mathrm{N}$ & 1 & 10 & 17 & 11 \\
\hline & $\%$ & $2.9 \%$ & $4.0 \%$ & $6.0 \%$ & $3.9 \%$ \\
\hline \multirow[t]{2}{*}{ Moderate } & $\mathrm{N}$ & 27 & 171 & 203 & 198 \\
\hline & $\%$ & $79.4 \%$ & $9.2 \%$ & $72.2 \%$ & $70.5 \%$ \\
\hline \multirow[t]{2}{*}{ Good } & $\mathrm{N}$ & 6 & 66 & 61 & 72 \\
\hline & $\%$ & $17.6 \%$ & $26.7 \%$ & $21.7 \%$ & $25.6 \%$ \\
\hline \multirow[b]{2}{*}{ Total } & $\mathrm{N}$ & 34 & 247 & 281 & 281 \\
\hline & $\%$ & $100 \%$ & $100 \%$ & $100 \%$ & $100 \%$ \\
\hline & Value & & & & \\
\hline Pearson Chi-Square Test & $p$-value & & & & \\
\hline & Mean & 0.7868 & 0.8067 & 0.7891 & 0.8043 \\
\hline Descriptive Analysis & SD & 0.1089 & 0.1268 & 0.1259 & 0.1247 \\
\hline Shapiro-Wilk test of Normality & $p$-value & 0.000 & 0.000 & 0.000 & 0.000 \\
\hline & & Man & Test & Wilcox & d Ranks \\
\hline & M.Rank & 131.25 & 142.34 & Pos & к: 11 \\
\hline & $\mathrm{Z}$ & & & & \\
\hline Testing Mean Difference & $p$-value & & & & \\
\hline
\end{tabular}


Table 3. Materials Used in the Walls, Floor and Roof

\begin{tabular}{|c|c|c|c|c|c|}
\hline \multicolumn{2}{|c|}{ Materials used in Walls of the House } & \multicolumn{2}{|c|}{ Membership Status } & \multicolumn{2}{|c|}{ Participation Status } \\
\hline & & \multirow{2}{*}{$\begin{array}{c}\text { New } \\
25 \\
\end{array}$} & \multirow{2}{*}{$\begin{array}{l}\text { Old } \\
201 \\
\end{array}$} & \multirow{2}{*}{$\begin{array}{c}\text { Before } \\
240 \\
\end{array}$} & \multirow{2}{*}{$\begin{array}{c}\text { After } \\
226 \\
\end{array}$} \\
\hline Temporary Materials (0) & $\mathrm{N}$ & & & & \\
\hline (Wood/Plastic/Zinc/Bamboo) & $\%$ & $73.5 \%$ & $81.4 \%$ & $85.4 \%$ & $80.4 \%$ \\
\hline \multirow{2}{*}{$\begin{array}{l}\text { Permanent Materials (1) } \\
(\text { Cement/Stone })\end{array}$} & $\mathrm{N}$ & 9 & 46 & 41 & 55 \\
\hline & $\%$ & $2.5 \%$ & $18.6 \%$ & $14.6 \%$ & $19.6 \%$ \\
\hline \multirow[b]{2}{*}{ Pearson Chi-Square Test } & Value & \multicolumn{2}{|c|}{1.1690} & \multicolumn{2}{|c|}{197.2534} \\
\hline & $p$-value & \multicolumn{2}{|c|}{$0.279>0.05$} & \multicolumn{2}{|c|}{$0.000<0.05$} \\
\hline \multirow[b]{2}{*}{ Descriptive Analysis } & Mean & 0.2647 & 0.1862 & 0.1459 & 0.1957 \\
\hline & SD & 0.4478 & 0.3900 & 0.3536 & 0.3974 \\
\hline Shapiro-Wilk test of Normality & $p$-value & 0.000 & 0.000 & 0.000 & 0.000 \\
\hline \multirow{4}{*}{ Testing Mean Difference } & & \multicolumn{2}{|c|}{ Mann-Whitney Test } & \multicolumn{2}{|c|}{ Wilcoxon Signed Ranks } \\
\hline & M.Rank & 150.69 & 139.67 & Pos & $: 14$ \\
\hline & $\mathrm{Z}$ & \multicolumn{2}{|c|}{-1.0792} & \multicolumn{2}{|c|}{-3.7416} \\
\hline & $p$-value & \multicolumn{2}{|c|}{$0.280>0.05$} & \multicolumn{2}{|c|}{$0.000<0.05$} \\
\hline \multicolumn{6}{|c|}{ Materials used in the floor of the House } \\
\hline \multirow{2}{*}{$\begin{array}{l}\text { Temporary Materials }(0) \\
\text { (Wood/Plastic/Zinc/Bamboo) }\end{array}$} & $\mathrm{N}$ & 26 & 211 & 237 & 237 \\
\hline & $\%$ & $76.9 \%$ & $85.4 \%$ & $84.3 \%$ & $84.3 \%$ \\
\hline \multirow{2}{*}{$\begin{array}{l}\text { Permanent Materials (1) } \\
\text { (Cement/Stone) }\end{array}$} & $\mathrm{N}$ & 8 & 36 & 44 & 44 \\
\hline & $\%$ & $23.5 \%$ & $14.6 \%$ & $15.7 \%$ & $15.7 \%$ \\
\hline & Value & & & & \\
\hline Pearson Chi-Square Test & $p$-value & & & & \\
\hline & Mean & 0.2353 & 0.1457 & & \\
\hline Descriptive Analysis & SD & 0.4305 & 0.3535 & & \\
\hline Shapiro-Wilk test of Normality & & 0.000 & 0.000 & & \\
\hline & & Manı & Test & & \\
\hline & M.Rank & 152.06 & 139.48 & & \\
\hline & Z & & & & \\
\hline Testing Mean Difference & $p$-value & & & & \\
\hline Materials used in the Roof of $t$ & & & & & \\
\hline Temporary Materials (0) & $\mathrm{N}$ & 33 & 245 & 278 & 278 \\
\hline (Wood/Plastic/Zinc/Bamboo) & $\%$ & $97.1 \%$ & 99.2 & $98.9 \%$ & $98.9 \%$ \\
\hline Permanent Materials (1) & $\mathrm{N}$ & 1 & 2 & 3 & 3 \\
\hline$($ Cement/Stone $)$ & $\%$ & $2.9 \%$ & $0.8 \%$ & $1.1 \%$ & $1.1 \%$ \\
\hline & $\mathrm{N}$ & 34 & 247 & 281 & 281 \\
\hline Total & $\%$ & $100 \%$ & $100 \%$ & $100 \%$ & $100 \%$ \\
\hline & Value & & & & \\
\hline Pearson Chi-Square Test & $p$-value & & & & \\
\hline & Mean & 0.0294 & 0.0081 & & \\
\hline Descriptive Analysis & SD & 0.1715 & 0.0898 & & \\
\hline Shapiro-Wilk test of Normality & $p$-value & 0.000 & 0.000 & & \\
\hline & & Mant & Test & & \\
\hline & M.Rank & 143.63 & 140.64 & & \\
\hline & $\mathrm{Z}$ & & & & \\
\hline Testing Mean Difference & $p$-value & & & & \\
\hline
\end{tabular}


Table 4. Sources of Drinking Water, Cooking Fuel and Toilet Facilities

\begin{tabular}{|c|c|c|c|c|c|}
\hline \multicolumn{2}{|l|}{ Sources of Drinking Water } & \multicolumn{2}{|c|}{ Membership Status } & \multicolumn{2}{|c|}{ Participation Status } \\
\hline & & \multirow{2}{*}{$\begin{array}{c}\text { New } \\
2 \\
\end{array}$} & \multirow{2}{*}{$\begin{array}{c}\text { Old } \\
17 \\
\end{array}$} & \multirow{2}{*}{$\begin{array}{c}\text { Before } \\
28\end{array}$} & \multirow{2}{*}{$\begin{array}{c}\text { After } \\
28\end{array}$} \\
\hline Unsafe (0) & $\mathrm{N}$ & & & & \\
\hline (River/rain/pond water) & $\%$ & $5.9 \%$ & $6.9 \%$ & $9.96 \%$ & $9.96 \%$ \\
\hline \multirow{2}{*}{$\begin{array}{l}\text { Safe Sources (1) } \\
\text { (Tap/Bottled Water) }\end{array}$} & $\mathrm{N}$ & 32 & 230 & 253 & 253 \\
\hline & $\%$ & $94.1 \%$ & $93.1 \%$ & $90.04 \%$ & $90.04 \%$ \\
\hline \multirow[b]{2}{*}{ Total } & $\mathrm{N}$ & 34 & 247 & 281 & 281 \\
\hline & $\%$ & $100 \%$ & $100 \%$ & $100 \%$ & $100 \%$ \\
\hline \multirow[b]{2}{*}{ Pearson Chi-Square Test } & Value & \multicolumn{2}{|c|}{0.0474} & \multicolumn{2}{|c|}{184.1285} \\
\hline & $p$-value & \multicolumn{2}{|c|}{$0.827>0.05$} & \multicolumn{2}{|c|}{$0.000<0.05$} \\
\hline \multirow[b]{2}{*}{ Descriptive Analysis } & Mean & 0.9412 & 0.9312 & 0.9004 & 0.9324 \\
\hline & SD & 0.2388 & 0.2536 & 0.3000 & 0.2515 \\
\hline Shapiro-Wilk test of Normality & $p$-value & 0.000 & 0.000 & 0.000 & 0.000 \\
\hline \multirow[b]{4}{*}{ Testing Mean Difference } & & \multicolumn{2}{|c|}{ Mann-Whitney Test } & \multicolumn{2}{|c|}{ Wilcoxon Signed Ranks } \\
\hline & M.Rank & 142.24 & 140.83 & \multicolumn{2}{|c|}{ Positive Rank: 9} \\
\hline & $\mathrm{Z}$ & \multicolumn{2}{|c|}{-0.2173} & \multicolumn{2}{|c|}{-3.000} \\
\hline & $p$-value & \multicolumn{2}{|c|}{$0.828>0.05$} & & \\
\hline Sources of Cooking Fuel & & & & & \\
\hline Environmentally More Distractive Sources & $\mathrm{N}$ & 2 & 6 & 14 & 8 \\
\hline (0) (Wood/Coal/Dung) & $\%$ & $5.9 \%$ & $2.4 \%$ & $5.0 \%$ & $2.8 \%$ \\
\hline Environmentally Less Distractive Sources & $\mathrm{N}$ & 32 & 241 & 267 & 273 \\
\hline (1) (Gas/Electricity) & $\%$ & $94.1 \%$ & $97.6 \%$ & $95.0 \%$ & $97.2 \%$ \\
\hline & $\mathrm{N}$ & 34 & 247 & 281 & 281 \\
\hline Total & $\%$ & $100 \%$ & $100 \%$ & $100 \%$ & $100 \%$ \\
\hline & Value & & & & \\
\hline Pearson Chi-Square Test & $p$-value & & & & \\
\hline & Mean & 0.9412 & 0.9757 & 0.9502 & 0.9715 \\
\hline Descriptive Analysis & SD & 0.2388 & 0.1542 & 0.2179 & 0.1666 \\
\hline Shapiro-Wilk test of Normality & $p$-value & 0.000 & 0.000 & 0.000 & 0.000 \\
\hline & & Mann & Test & Wilcox & d Ranks \\
\hline & M.Rank & 136.74 & 141.59 & Posit & : 6 \\
\hline & Z & & & & \\
\hline Testing Mean Difference & $p$-value & & & & \\
\hline Sources of Toilet Facilities & & & & & \\
\hline Environmentally Unsafe (0) (Tradition Open & $\mathrm{N}$ & 2 & 6 & 8 & 8 \\
\hline Toilet) & $\%$ & 5.9 & 2.4 & 2.8 & 2.8 \\
\hline Environmentally Safe (1) (Flash / Cement & $\mathrm{N}$ & 32 & 241 & 273 & 273 \\
\hline Toilet) & $\%$ & 94.1 & 97.6 & 97.2 & 97.2 \\
\hline & $\mathrm{N}$ & 34 & 247 & 281 & 281 \\
\hline Total & $\%$ & $100 \%$ & $100 \%$ & $100 \%$ & $100 \%$ \\
\hline & Value & & & & \\
\hline Pearson Chi-Square Test & $p$-value & & & & \\
\hline & Mean & 0.9411 & 0.9797 & & \\
\hline Descriptive Analysis & SD & 0.2388 & 0.1674 & & \\
\hline Shapiro-Wilk test of Normality & $p$-value & 0.000 & 0.000 & & \\
\hline & & Man & y Test & & \\
\hline & M.Rank & 136.26 & 141.65 & & \\
\hline & $\mathrm{Z}$ & & & & \\
\hline Testing Mean Difference & $p$-value & & & & \\
\hline
\end{tabular}


Table 5. Impact on Quality of Life

\begin{tabular}{|c|c|c|c|}
\hline & & Before & After \\
\hline \multicolumn{2}{|l|}{ Mean } & 6.8950 & 7.0525 \\
\hline \multicolumn{2}{|l|}{ Standard Deviation } & 0.7688 & 0.7197 \\
\hline Shapiro-Wilk test of Normality & $p$-value & 0.000 & 0.000 \\
\hline \multirow{3}{*}{ Wilcoxon Signed Ranks Test } & & \multicolumn{2}{|c|}{ Positive Rank: 65} \\
\hline & $\mathrm{Z}$ & \multicolumn{2}{|c|}{-7.0941} \\
\hline & $p$-value & \multicolumn{2}{|c|}{$0.000<0.05$} \\
\hline
\end{tabular}

